\title{
A NEW SPECIES OF TARRACOBLANIULUS MAURIÈS \& VICENTE, 1977: DESCRIPTION, POSTEMBRYONIC DEVELOPMENT, LIFE CYCLE, AND SPATIAL DISTRIBUTION (DIPLOPODA, JULIDA, BLANIULIDAE)
}

\author{
H. Enghoff ${ }^{1}$, A. Serra ${ }^{2}$ \& H. Martínez ${ }^{2}$
}

\begin{abstract}
Tarracoblaniulus phantasmanus $\mathbf{n}$. sp. is described from Tarragona province, Spain and compared with the only known other species known in the genus, T. lagari Mauriès \& Vicente, 1977, from which it differs mainly in having only 5, instead of 15 or more, straight spines on the posterior gonopod. The female vulva (unknown in T. lagari) is very different from all known blaniulid vulvae. Based on a large number of specimens, the postembryonic development (euanamorphosis) from stadium II onward is described. This is highly variable, with three to six apodous body rings in stadium IV, which is the most variable number so far recorded in Blaniulidae. Accordingly, specimens beyond stadium VIII could not be assigned to a specific stadium. At least some males are morphologically distinguishable in stadium IV, morphologically mature males appear in stadium VIII, possibly already in stadium VII. The life cycle of the new species is tentatively suggested to involve at least three years. The monthly mean density of the total population was $28.82 \mathrm{ind} / \mathrm{m}^{2}$ across the whole soil profile. Statistically significant differences in density values between months and Spearman's rank correlation analyses between the monthly mean values of density and temperature show that $T$. phantasmanus presents a maximum density in the coldest months and a minimum one in the summer. Significant differences between monthly mean densities of different soil levels and the Usher index values show that during the spring and summer T. phantasmanus is concentrated in the mineral horizon A. In autumn, during winter and up to early spring, the population shows a clear tendency to move up towards horizon $\mathrm{H}$ and horizon $\mathrm{L} / \mathrm{F}$. Concerning horizontal distribution, Morisita index monthly values for each of the horizons indicate that the species is distributed in patches.
\end{abstract}

Key words: millipede, taxonomy, anamorphosis, life cycle, spatial distribution, Spain.

\section{RESUMEN}

Una nueva especie de Tarracoblaniulus Mauriès \& Vicente, 1977: descripción, desarrollo postembrionario, ciclo vital y distribución espacial (Diplopoda, Julida, Blaniulidae)

Se describe Tarracoblaniulus phantasmanus $\mathbf{n}$. sp., especie encontrada en la provincia de Tarragona (España), y se compara con la única especie conocida del género, $T$.

Natural History Museum of Denmark, University of Copenhagen, Universitetsparken 15, DK-2100 Koebenhavn OE, Denmark. E-mail: henghoff@snm.ku.dk

2 Departament de Biologia Animal, Facultat de Biologia, Universitat de Barcelona, Avda. Diagonal, 645, Barcelona (08028), Spain. E-mail: aserra@ub.edu 
lagari Mauriès \& Vicente, 1977, de la cual difiere principalmente por tener sólo 5 espinas, en lugar de 15 o más, en el gonópodo posterior. La vulva de la hembra (desconocida en T. lagari) es muy distinta a todas las vulvas conocidas de blaniúlidos. En base a los numerosos ejemplares disponibles, se describe asimismo el desarrollo postembrionario (euanamorphosis) a partir del estadio II. Este desarrollo se manifiesta muy variable, con tres a seis anillos ápodos en el tronco del estadio IV, número que con mucho es el más elevado encontrado en Blaniulidae. De acuerdo con estos resultados, los ejemplares pertenecientes a estadios posteriores al VII no pueden ser asignados a un estadio específico. Algunos machos son morfológicamente distinguibles en el estadio IV y los machos morfológicamente maduros aparecen en el estadio VIII y posiblemente ya lo sean en el estadio VII. El ciclo vital de la nueva especie parece sugerir una duración de al menos tres años. La densidad mensual media registrada para el total de la población es de $28.82 \mathrm{ind} / \mathrm{m}^{2}$ en el conjunto del perfil edáfico. Diferencias estadísticamente significativas entre los valores de densidad mensuales y el análisis de correlación de rango de Spearman entre la densidad mensual media y la temperatura muestran que T. phantasmanus presenta una densidad máxima en los meses más fríos y un valor mínimo durante el verano. Diferencias siginificativas entre las densidades mensuales medias registradas en los distintos horizontes edáficos y los valores del índice de Usher, ponen de manifiesto que durante la primavera y el verano T. phantasmanus se situa principalmente en el horizonte mineral A. Durante el otoño, el invierno y hasta principios de la primavera, la población muestra una clara tendencia a ocupar los horizontes superiores $\mathrm{H}$ y L/F. En cuanto a la distribución horizontal, los valores mensuales del índice de Morisita obtenidos para cada uno de los horizontes indican que la especie tiene una distribución agregativa.

Palabras clave: diplópodos, taxonomía, anamorfosis, ciclo vital, distribución espacial, España.

\section{Introduction}

The genus Tarracoblaniulus was described by Mauriès \& Vicente (1977) for the new species $T$. lagari, a cave-dwelling species from Cova Janet (Spain, Tarragona, Llaveria, N $41^{\circ} 8^{\prime} 25^{\prime \prime}$ E $0^{\circ} 46^{\prime} 58^{\prime \prime}$ ). Since the original description, no specimens of Tarracoblaniulus have been reported.

However, soil samples taken by AS and HM in Bosc de Poblet (Muntanyes de Prades), municipality of Vimbodí, province of Tarragona, Catalonia, Spain, contained numerous specimens of an undescribed species of Tarracoblaniulus. This site is just $35 \mathrm{~km}$ from the type locality of $T$. lagari. In this paper, we describe the new species, and because of the very abundant material, we are also in a position to present an analysis of its postembryonic development (anamorphosis) as well as some analyses of its life cycle and spatial distribution.

\section{Material and methods}

\section{LOCATION}

The study site is located in the Bosc de Poblet (Muntanyes de Prades), municipality of Vimbodí, province of Tarragona, Catalonia, Spain (UTM coordinates 31TCF3980). The study was performed in a mountain oak wood (Quercetum mediterraneomontanum), sclerophyllous forest consisting mainly of Quercus ilex accompanied by species with a more Euro-Siberian distribution: Taxus baccata, Ilex aquifolium, Pinus sylvestris and Corylus avellana. Humus is of the mullmoder type, with an average $\mathrm{pH}$ value of 5.91 (measured in 1:2.5 water). The site is placed between 1000 and $1010 \mathrm{~m}$ above sea level. The climate of this region is typically Mediterranean. Fig. 1 depicts the total rainfall and mean monthly temperatures recorded on the site during the sampling period.

\section{SAMPLING}

Samples were obtained in the field during 13 consecutive months from May 2002 to May 2003. In an experimental plot (40 x $40 \mathrm{~m})$, three soil horizons were sampled: L/F, H, and A (leaf litter fall, humus and the first three $\mathrm{cm}$ of the mineral layer, respectively). A cylindrical corer, $0.36 \mathrm{~m}$ in diameter (equivalent to $0.102 \mathrm{~m}^{2}$ ), was used for sampling. Each monthly sample included five sampling units randomly taken. Millipedes were extracted over a 25 day period with Berlese-Tullgren funnels. Pitfall 


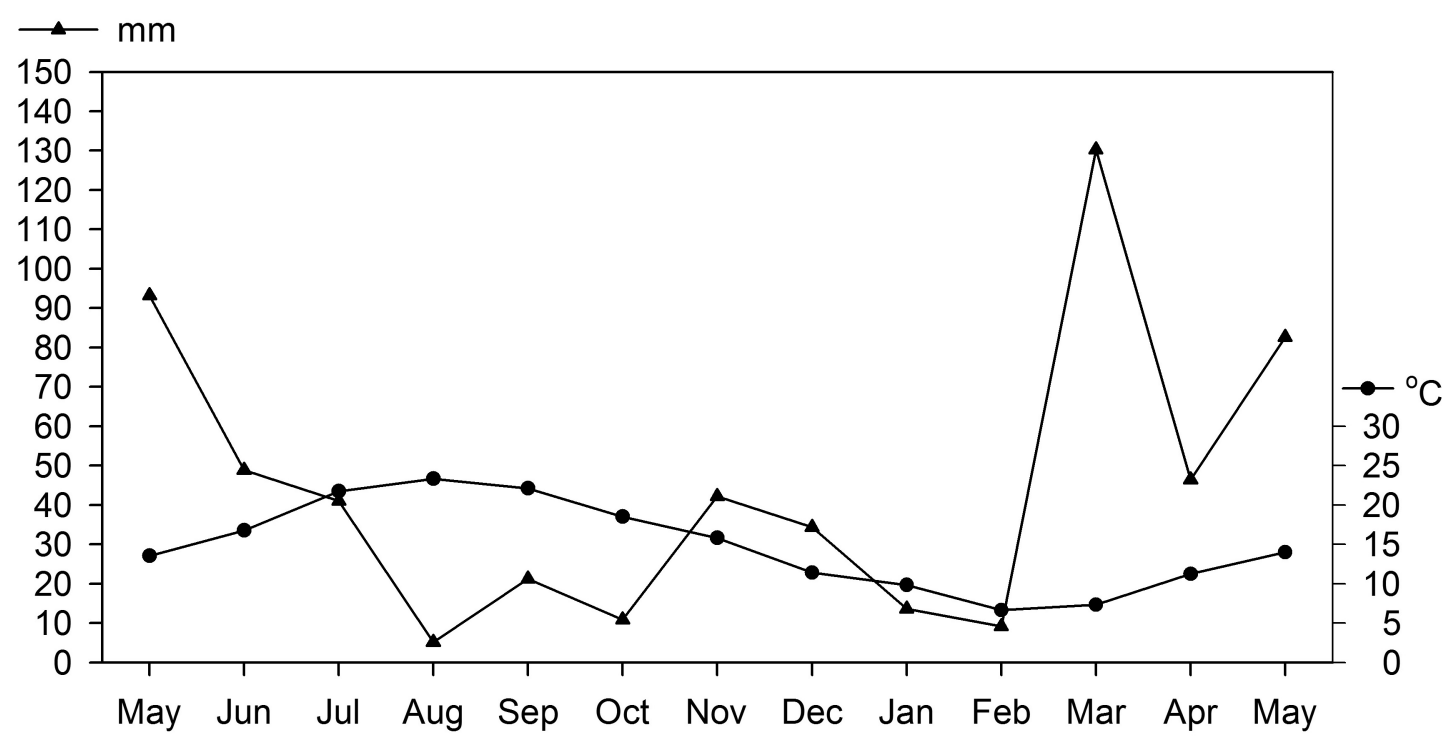

Fig. 1.- Monthly rainfall $(\mathrm{mm})$ and mean temperatures $\left({ }^{\circ} \mathrm{C}\right)$ recorded at the study site during the sampling period.

Fig. 1.- Precipitaciones mensuales $(\mathrm{mm})$ y temperaturas medias $\left({ }^{\circ} \mathrm{C}\right)$ registradas en el lugar de estudio durante el periodo de muestreo.

traps were set in another plot on the same site but no Tarracoblaniulus specimens were captured this way.

\section{NUMERICAL METHODS}

Mean population density values (ind $/ \mathrm{m}^{2}$ ) were calculated in each soil horizon for each month $(n=$ $5)$ and for the whole sampling period $(n=13)$.

The differences in density values between samples were compared by means of Kruskal-Wallis (KW) and Mann-Whitney U-test methods (Sokal \& Rohlf, 1995). A posteriori comparisons were carried out using Student-Newman-Keuls (SNK) (Newman, 1939; Keuls, 1952). Spearman's rank correlation coefficient (Spearman, 1904) was used to relate abiotic parameters (mean monthly air temperature and monthly accumulated rainfall) to population density parameters.

The Usher index (Usher, 1975) was used to estimate the vertical distribution of the Tarracoblaniulus population through the soil profile. Arbitrary depth values were designated for each horizon: 3 for L/F, 2 for $\mathrm{H}$ and 1 for $\mathrm{A}$. For each monthly value of this index $\left(\mathrm{U}_{\mathrm{i}}\right)$, an error $\mathrm{S}_{\mathrm{i}}$ was calculated following Usher's method.

The Morisita dispersion index (Elliott, 1977) was used to estimate the horizontal distribution of the population.

\section{STUDY OF SPECIMENS}

Counts of podous and apodous body rings were made on all entire or reconstructable specimens. Based on these counts, the postembryonic development was described, applying the "rule of anamorphosis" according to which, in ring-forming millipedes such as Julida, apodous rings in postembryonic stadium $\mathbf{n}$ turn podous in stadium $\mathbf{n}+\mathbf{1}$ where at the same time a number of new apodous rings are added in front of the telson (Enghoff et al., 1993).

Scanning electron micrographs were obtained with a Jeol JSM-6335F Field Emission SEM (ZMUC). Extended focus photographs of vulvae were obtained with the Automontage software.

\section{Tarracoblaniulus phantasmanus $\mathbf{n}$. sp.}

\section{(Figs. 2-13)}

Holotype: male, SPAIN, Catalonia, Vimbodí (Tarragona), Bosc de Poblet (Muntanyes de Prades), Pic de l'Aliga, 1000$1010 \mathrm{~m}$ above sea level, (N 4121'7' E 1'5'42', UTM coordinates 31TCF3980), 7 November 2002, A. Serra \& H. Martínez leg. (Centre de Recursos de Biodiversitat Animal, Universitat de Barcelona [CRBA], collection number CRBA1295).

PARATYPES: 3 males, 3 females, same locality as holotype, 2 May 2002 - 6 May 2003, same collectors (CRBA), collection numbers CRBA1296 to CRBA1301; 2 males, 2 females, same 

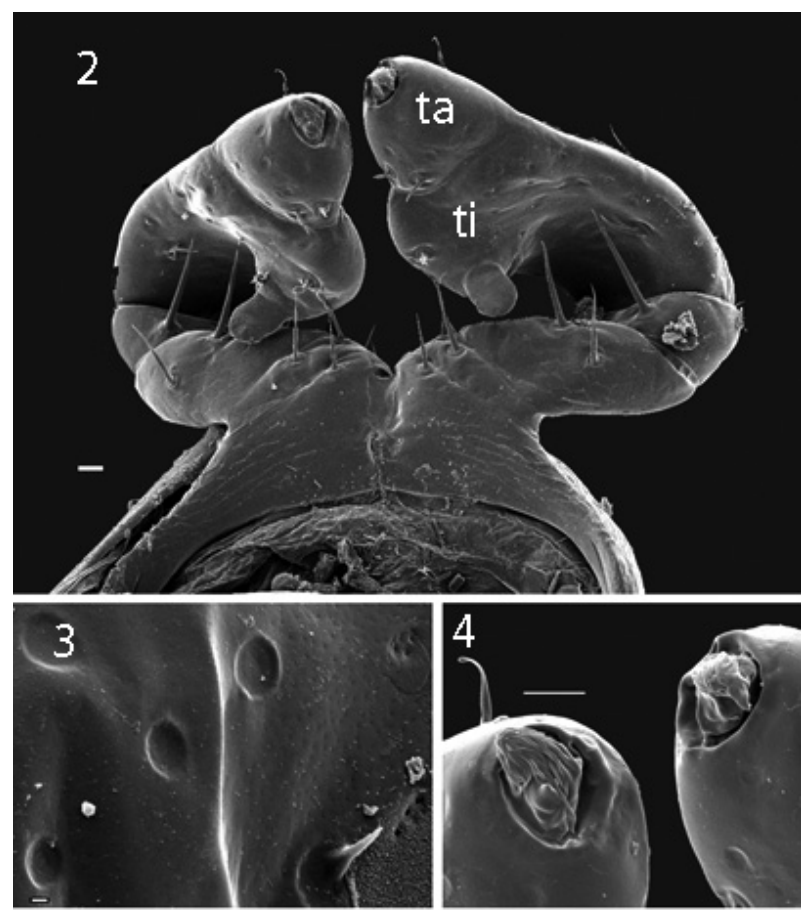

Figs. 2-4.- Tarracoblaniulus phantasmanus, first pair of male legs. 2) Anterior view, scale $0.01 \mathrm{~mm} .3$ ) Detail of tarsus, showing subcircular depressions, scale $0.001 \mathrm{~mm}$. 4). Rudimentary claws, scale $0.01 \mathrm{~mm}$. - ta: tarsus, tb: tibia.

Figs. 2-4.- Tarracoblaniulus phantasmanus, primer par de patas del macho. 2) Vista anterior, escala $0.01 \mathrm{~mm}$. 3) Detalle del tarso, donde se observan depresiones subcirculares, escala $0.001 \mathrm{~mm}$. 4) Uñas rudimentarias, escala $0.01 \mathrm{~mm}$. - ta: tarso, tb: tibia.

data (Natural History Museum of Denmark [ZMUC], collection number ZMUC 100753).

AdDitional MATERial: 171 females and juveniles, same data (CRBA).

Diagnosis: A species of Tarracoblaniulus characterized by the small number (5) of straight, distal spines on the posterior gonopod, as opposed to 15 or more in T. lagari (cf. drawings in Mauriès \& Vicente 1977). Agrees with the type species, $T$. lagari, as described by Mauriès \& Vicente (1977) in all characters not specified below.

DESCRIPTION: Body length 6.5-9 mm in males (M), max. $9 \mathrm{~mm}$ in females (F). Midbody vertical diameter $0.44-0.52 \mathrm{~mm}(\mathrm{M})$, $\max .0 .55 \mathrm{~mm}(\mathrm{~F})$, body slightly laterally compressed. $32-40$ podous body rings in $\mathrm{M}$, max. 43 in $\mathrm{F}$.

Colour uniformly pale brown.
Antennae 1.8 (1.6) x body diameter in $\mathrm{M}(\mathrm{F})$. Relative lengths $(\%)$ of antennomeres 2-8 (8 = apical sensilla): 19-21/18/17/19/15-16/6-7/4. Apical sensilla 4.2-4.9 x longer than broad. Two long frontal setae. No eyes.

Body rings with a slight constriction between pro- and metazona, both of which slightly vaulted. Metazona with longitudinal striae in ventral half and with a posterior whorl of ca. 12 setae, length of setae $0.22-0.29 \mathrm{x}$ body diameter.

Legs $0.7(0.6) \mathrm{x}$ body diameter in $\mathrm{M}(\mathrm{F})$. Relative lengths of podomeres: prefemur 14-15 / femur 18 / postfemur 12-16 / tibia 14 / tarsus 24-26 / claw 1415. Tarsus $4 \mathrm{x}$ longer than high, claw 5-6 x longer than high. Accessory claw very much shorter than claw on anterior legs, decreasing in length going backwards, barely traceable on midbody legs.

Male SeXual Characters: Mandibles with typical blaniulid "parrot bill" modifications of cardo and stipes. First pair of legs (Figs. 2-4) as described for $T$. lagari, i.e., with the tibia large, curved and flattened, tibial apophysis with one hypertrophied seta; claw (Fig. 4) rudimentary. Surface of tibia and tarsus with tiny, subcircular depressions (Fig. 3). Lanceolate leg setae on femur (2), postfemur (1-2) and tibia (1-2) of anterior and midbody legs. Ventral margins of pleurotergum 7 simple, parallelsided in anterior $2 / 3$, posteriorly with triangular mesal projections; no horizontal flanges like those in Acipes and Proteroiulus (Enghoff, 1983).

Anterior gonopods (Fig. 5) as in T. lagari, i.e., with large coxal projections which are only fused basally, thereafter separated by an ovoid aperture for a short distance, and closely juxtaposed for the rest of their length; their lateral margins shallowly sinuous, their apical margins characteristically emarginated. Telopodites less than half as long as coxal projections, each with 4 apical setae.

Posterior gonopods (Fig. 6) with a strongly curved shaft (the strong curvature is not an artefact due to desiccation for SEM), apically divided into two branches: a simple spine-like branch $(a)$ and one $(b)$ which carries one long curved spine $(b s)$ basally, five long, almost straight spines more distally, and one tiny apical spine.

FEMALE SEXUAL CHARACTERS: Antennae without modifications. Second pair of legs with independent coxae, as in Blaniulus guttulatus (Fabricius, 1798) (Brolemann, 1923: figs 292-294).

Vulval invaginations deep, reaching into body ring 6. Vulvae (Fig. 7) pyriform; operculum and bursa of approximately equal length, closely pressed against each other; operculum with ca. 5 


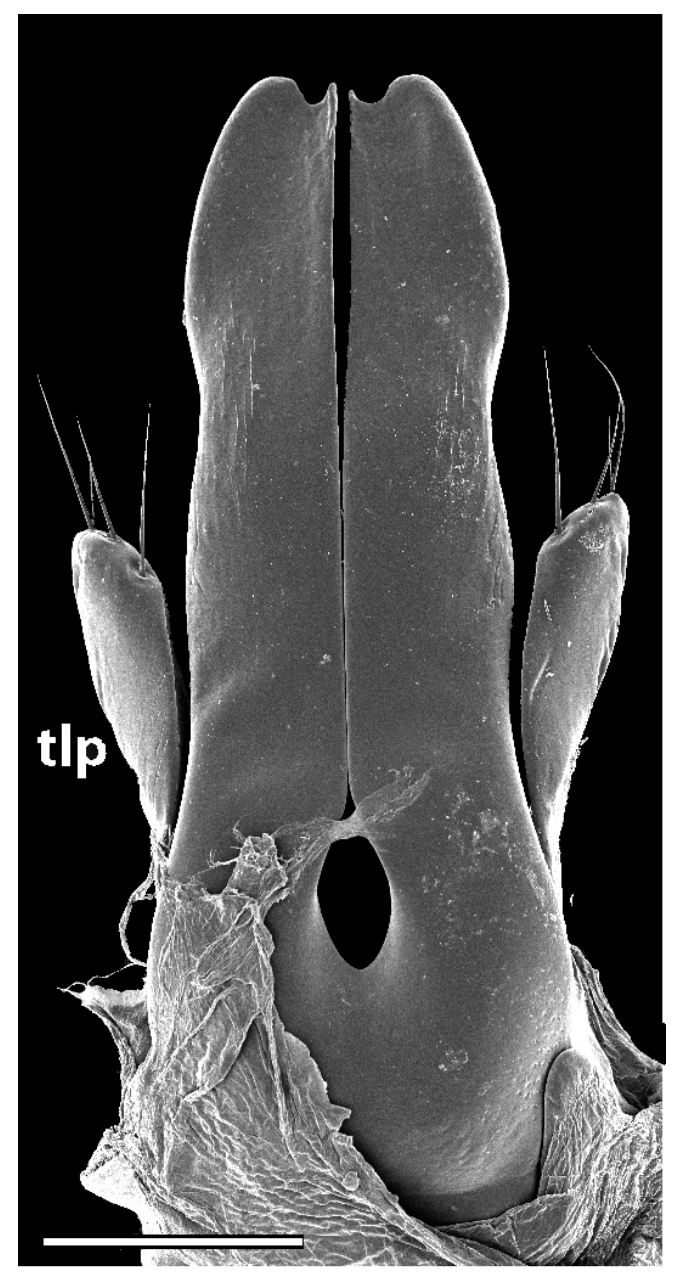

Fig. 5.- Tarracoblaniulus phantasmanus, anterior gonopods, anterior view, scale $0.1 \mathrm{~mm}$. - tlp: telopodite.

Fig. 5.- Tarracoblaniulus phantasmanus, vista anterior de los gonópodos anteriores, escala $0.1 \mathrm{~mm}$. - tlp: telopodito.

setae on anterior side; valves of bursa each with ca. 4 setae, valves widely separated, leaving the crest ("cimier") of the bursa clearly visible in posterior view; crest with a membranous protrusion $(\mathrm{mp})$; receptaculum seminis $(r s)$ simple, tubular.

ETYMOLOGY: The specific name is an artificial composite noun, from Greek phantasma (ghost) and Latin manus (hand) and refers to the shape of the tip of the posterior gonopod which looks quite like how one might imagine a ghost's hand.

TAXONOMIC DISCUSSION: The marked difference in the number of distal spines on the posterior gonopod ( 5 vs. $15+$ ) clearly distinguishes the two

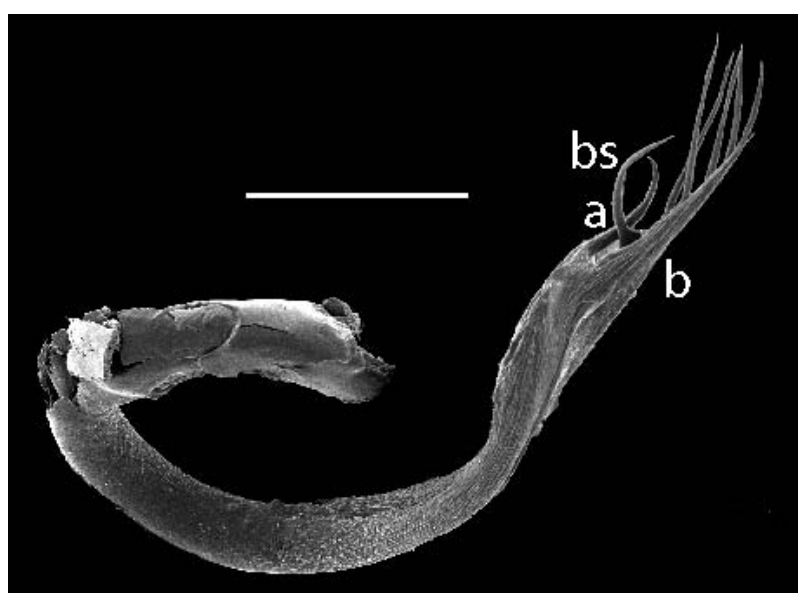

Fig. 6.- Tarracoblaniulus phantasmanus, right posterior gonopod, mesal view, scale $0.1 \mathrm{~mm}$. - a: simple branch, b: branch with spines, bs: basal spine of branch $b$.

Fig. 6.- Tarracoblaniulus phantasmanus, vista mesial del gonópodo posterior derecho, escala $0.1 \mathrm{~mm}$. - a: rama simple, b: rama con espinas, bs: espina basal de la rama b.

species of Tarracoblaniulus which are otherwise very similar. T. phantasmanus seems to be somewhat smaller than $T$. lagari for the only male specimen of which Mauriès \& Vicente recorded the body length as $11 \mathrm{~mm}$ and the vertical body diameter as $0.65 \mathrm{~mm}$. Males of T. phantasmanus are up to $9 \mathrm{~mm}$ long and up to $0.52 \mathrm{~mm}$ in vertical diameter. However, Mauriès \& Vicente (1977) did not inform about the number of body rings in T. lagari which complicates the comparison. The antenna length of T. lagari was recorded as $1 \mathrm{~mm}$, which would correspond to $1.5 \mathrm{x}$ body diameter, compared to $1.8 \mathrm{x}$ in T. phantasmanus. Mauriès \& Vicente (1977) did not mention metazonal setae for $T$. lagari whereas these are prominent in $T$. phantasmanus (but their absence in the only specimen of T. lagari might be due to wear).

Mauriès \& Vicente (1977) defined the genus Tarracoblaniulus as a genus of Blaniulini (sensu Mauriès, 1970) which differs from the other genera in the tribe ${ }^{1}$ by the deep division of the distal part of the posterior gonopod into two branches: one simple,

\footnotetext{
Blaniulus Gervais, 1836 (incl. Typhloblaniulus Verhoeff, 1898), Monacobates Verhoeff, 1911, Sardoblaniulus Manfredi, 1956, Occitaniulus Mauriès, 1965, and Vascoblaniulus Mauriès, 1967. Proteroiulus Silvestri, 1897, was also included in Blaniulini by Mauriès (1970); however, Enghoff (1983) suggested that this genus should be moved to the Acipedini (Acipini in Mauriès, 1970).
} 


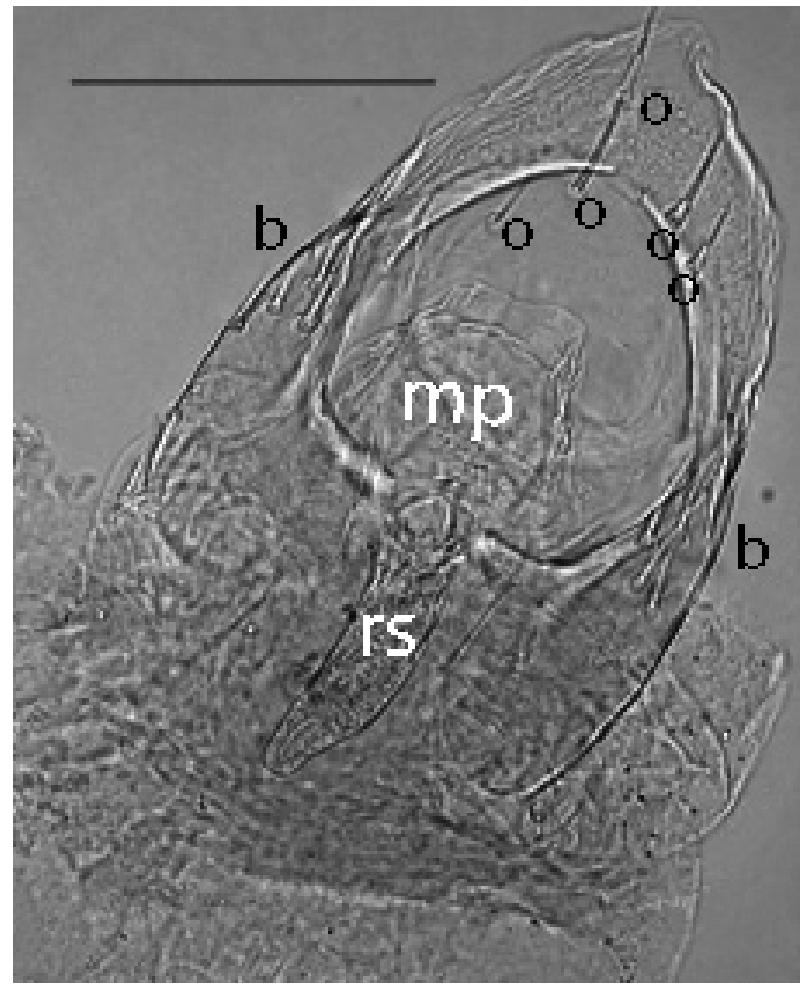

Fig. 7.- Tarracoblaniulus phantasmanus, left vulva, scale 0.1 $\mathrm{mm}$. - b: setae of bursa (two oval fields), mp: membraneous protrusion of crest, o: setae of operculum, rs: receptaculum seminis.

Fig. 7.- Tarracoblaniulus phantasmanus, vulva izquierda, escala $0.1 \mathrm{~mm}$.-b. sedas de la bursa (dos campos ovalados), mp: extensión membranosa de la cresta, o: sedas del opérculo, rs: receptáculo seminal.

pointed branch and the other terminating in a bunch of "ribbons" (corresponding to what we call spines). They further emphasized that the coxal processes of the anterior gonopods are fused only at their base.

This differential diagnosis of Tarracoblaniulus is still useful although the separation between the two branches of the posterior gonopods is not quite as distinctive in the new species as it seems to be in the type species according to Mauriès \& Vicente's figure 22a. The characteristic shape of the coxal processes of the anterior gonopods, in particular their emarginate tips, may be added to the diagnosis, together with the shape of the first pair of male legs, esp. the long, curved and flattened penultimate podomere (tibia).

The second pair of female legs resembles those of Blaniulus guttulatus in having the coxae inde- pendent, neither fused to each other, nor to the sternum. Brolemann (1923: 162) pointed out that in all other members of the subfamily Blaniulinae (sensu Brolemann, 1923) known to him the coxae are at least partly fused. In this respect, Tarracoblaniulus phantasmanus and Blaniulus guttulatus resemble Mesoblaniulus serrula (Brölemann, 1905), only known member of tribe Mesoblaniluini sensu Brolemann (1923) -the independent second female coxae obviously constitute a plesiomorphy at the level of Blaniulidae ${ }^{2}$.

The vulva of T. phantasmanus is quite different from that found in all other blaniulids of which the vulvae have been described (Brolemann, 1923; Enghoff \& Shelley, 1979; Enghoff, 1983, 1984). In all these species the crest ("cimier" of Brolemann) is not visible on the external surface but is situated on the top of the bursa, or on the surface facing the operculum. The vulvae of T. lagari are unknown, so the level at which this character is significant remains uncertain.

POSTEMBRYONIC DEVELOPMENT (ANAMORPHOSIS): In Fig. 8, the body ring formulae of our material are shown. Each formula has been referred to a postembryonic stadium, applying the law of anamorphosis (cf. Enghoff et al., 1993). All specimens have at least one apodous ring, in agreement with the prevalence, in the order Julida, of euanamorphosis, i.e., a mode of postembryonic development in which new body rings are added at each moult and in which there is no fixed end-point of anamorphosis (Enghoff et al., 1993).

In the vast majority of juliformian millipedes, including all species of Blaniulidae in which the early anamorphosis has been described, the first juvenile stadium after the pupoid is a hexapod creature, having four podous body rings (including the collum) plus two apodous ring (excluding the telson). This stadium I is immobile in almost all blaniulid species. It is not represented in the material of Tarracoblaniulus phantasmanus at hand, but we assume that our species is similar to the other blaniulids in this respect. Under this assumption, the earliest stadium represented in our material will thus be stadium II. This stadium has six podous rings plus four or (by far most frequently) five apodous rings. Stadium II has seven pairs of legs.

In stadium III we find, as expected, a predominance of specimens with $11(6+5)$ podous rings and

Blaniulidae in the current sense (Enghoff, 1981) corresponds to Mesoblaniulini + Blaniulinae in Brolemann (1923). 


\begin{tabular}{|c|c|c|c|c|c|c|c|c|c|c|c|c|c|c|}
\hline st. II & & & & & & & $\begin{array}{c}\mathbf{6}+\mathbf{4} \\
{[4]}\end{array}$ & $\begin{array}{l}\mathbf{6}+\mathbf{5} \\
{[36]}\end{array}$ & & & & & & \\
\hline st. III & & & & & & $(10+4)$ & $\begin{array}{c}\mathbf{1 0}+\mathbf{5} \\
{[2]}\end{array}$ & $\begin{array}{c}\mathbf{1 1 + 4} \\
{[15]}\end{array}$ & $\begin{array}{c}\mathbf{1 1 + 5} \\
{[7]}\end{array}$ & & & & & \\
\hline st. IV & & & $\begin{array}{c}\mathbf{1 4 + 3} \\
{[1]}\end{array}$ & $\begin{array}{c}\mathbf{1 4}+\mathbf{6} \\
{[1]}\end{array}$ & $\begin{array}{c}\mathbf{1 5}+\mathbf{3} \\
{[1]}\end{array}$ & $\begin{array}{c}\mathbf{1 5}+\mathbf{4} \\
{[6]}\end{array}$ & $\begin{array}{c}\mathbf{1 5}+\mathbf{5} \\
{[8]}\end{array}$ & $\begin{array}{c}\mathbf{1 6}+\mathbf{3} \\
{[1]}\end{array}$ & $\begin{array}{c}\mathbf{1 6 + 4} \\
{[1]}\end{array}$ & $\begin{array}{c}\mathbf{1 6 + 5} \\
{[6]}\end{array}$ & $\begin{array}{c}\mathbf{1 6}+\mathbf{6} \\
{[2]}\end{array}$ & & & \\
\hline st. V & & & $(17+x)$ & $(18+x)$ & $\begin{array}{c}\mathbf{1 9 + 5} \\
{[1]}\end{array}$ & $\begin{array}{c}\mathbf{2 0}+\mathbf{5} \\
{[3]}\end{array}$ & $\begin{array}{c}\mathbf{2 1 + 4} \\
{[1]}\end{array}$ & $\begin{array}{c}\mathbf{2 1 + 5} \\
{[3]}\end{array}$ & $(21+6)$ & $(22+5)$ & $\begin{array}{c}\mathbf{2 2 + 6} \\
{[1]}\end{array}$ & & & \\
\hline st. VI & & & $\begin{array}{c}\mathbf{2 4}+\mathbf{4} \\
{[2]}\end{array}$ & $\begin{array}{c}\mathbf{2 4 + 5} \\
{[2]}\end{array}$ & $\begin{array}{c}\mathbf{2 5}+\mathbf{5} \\
{[5]}\end{array}$ & $\begin{array}{c}\mathbf{2 6}+\mathbf{4} \\
{[2]}\end{array}$ & $\begin{array}{c}\mathbf{2 6 + 5} \\
{[2]}\end{array}$ & $\begin{array}{c}\mathbf{2 7}+\mathbf{2} \\
{[1]}\end{array}$ & $\begin{array}{c}\mathbf{2 7}+\mathbf{3} \\
{[1]}\end{array}$ & $\begin{array}{c}\mathbf{2 7 + 4} \\
{[2]}\end{array}$ & $\begin{array}{c}28+4 \\
{[1]}\end{array}$ & & & \\
\hline st. VII & & $\begin{array}{c}28+4 \\
{[1]}\end{array}$ & $\begin{array}{c}\mathbf{2 9 + 3} \\
{[1]}\end{array}$ & $\begin{array}{c}29+4 \\
{[2]}\end{array}$ & $\begin{array}{c}\mathbf{3 0}+\mathbf{3} \\
{[1]}\end{array}$ & $\begin{array}{c}\mathbf{3 0}+\mathbf{4} \\
{[7]}\end{array}$ & $\begin{array}{c}\mathbf{3 1}+\mathbf{3} \\
{[4]}\end{array}$ & $\begin{array}{c}\mathbf{3 1 + 4} \\
{[5]}\end{array}$ & $\begin{array}{c}\mathbf{3 1}+\mathbf{5} \\
{[1]}\end{array}$ & $\frac{\mathbf{3 2 + 3}}{[1]}$ & $\frac{32+4}{[3]}$ & & & \\
\hline st. VIII & & $\frac{\mathbf{3 2 + 3}}{[1]}$ & $\begin{array}{c}\mathbf{3 2 + 4} \\
{[3]}\end{array}$ & $\begin{array}{c}\mathbf{3 3}+\mathbf{3} \\
{[2]}\end{array}$ & $\begin{array}{c}\mathbf{3 3}+\mathbf{4} \\
{[2]}\end{array}$ & $\begin{array}{c}\mathbf{3 4}+\mathbf{2} \\
{[1]}\end{array}$ & $\begin{array}{c}\mathbf{3 4 + 3} \\
{[3]}\end{array}$ & $\begin{array}{c}\mathbf{3 4 + 4} \\
{[1]}\end{array}$ & $\frac{\mathbf{3 5 + 2}}{[3]}$ & $\begin{array}{c}\mathbf{3 5 + 3} \\
{[2]}\end{array}$ & $\frac{\mathbf{3 6 + 2}}{[1]}$ & $\frac{\mathbf{3 6}+\mathbf{3}}{[4]}$ & & \\
\hline $\begin{array}{l}\text { st. IX } \\
\text { etc. }\end{array}$ & $\frac{\mathbf{3 5 + 2}}{[3]}$ & $\frac{\mathbf{3 5 + 3}}{[2]}$ & $\frac{\mathbf{3 6}+\mathbf{2}}{[1]}$ & $\frac{\mathbf{3 6}+\mathbf{3}}{[4]}$ & $\frac{\mathbf{3 7 + 2}}{[1]}$ & $\frac{\mathbf{3 8}+\mathbf{1}}{[1]}$ & $\begin{array}{c}\mathbf{3 8 + 2} \\
{[7]}\end{array}$ & $\frac{\mathbf{3 8}+\mathbf{3}}{[1]}$ & $\begin{array}{c}\mathbf{3 9 + 2} \\
{[2]}\end{array}$ & $\frac{\mathbf{3 9 + 3}}{[1]}$ & $\frac{\mathbf{4 0 + 2}}{[1]}$ & $\underset{[3]}{\mathbf{4 1 + 2}}$ & $\begin{array}{c}41+3 \\
{[1]}\end{array}$ & $\underset{[1]}{\mathbf{4 2 + 2}}$ \\
\hline
\end{tabular}

Fig. 8.- Tarracoblaniulus phantasmanus, body ring formulae referred to postembryonic stadia (st.). The formulae consist of the number of podous body rings (including the collum) plus the number of apodous rings (excluding the telson: preanal ring + anal valves + subanal scale). Formulae in bold have been observed. Formulae in parentheses are inferred (only inferred formulae "necessary" to account for the observed ones, and inferred formulae inevitably originating from observed ones, are indicated). Formulae on a highlighted background may belong to different stadia. Numbers of observed specimens are given below the formulae in small, italicized numbers in square brackets.

Fig. 8. - Tarracoblaniulus phantasmanus, fórmulas de los anillos del cuerpo referidas a los estadios postembrionarios (st.). Cada fórmula se refiere al número de anillos del cuerpo con patas (incluido el collum) y el número de anillos sin patas (excluyendo el telson: anillo preanal+valvas anales+escala subanal). En negrita se han resaltado las fórmulas observadas. Las fórmulas entre paréntesis son las deducidas a partir de las observaciones (sólo se han deducido fórmulas para aquellos casos en los que de otra forma no se tendrían en cuenta las observaciones y para los casos en que se han tenido que crear inevitablemente a partir de las observaciones, indicándose en ambos casos). Las fórmulas resaltadas son las que pueden pertenecer a diferentes estadios. El número de especímenes observados se indica bajo la fórmula entre corchetes, con menor tamaño y en itálica.

a smaller number of specimens with $10(6+4)$ podous rings. All in all, three body ring formulae are represented in our material: $10+5,11+4$ and $11+5$. We therefore expect to find 15 and 16 podous rings in stadium IV juveniles. These numbers are also predominant, but there are a few stadium IV specimens with 14 podous rings. We can therefore infer that stadium III specimens with $10+4$ or (less probably) $11+3$ rings exist. The observed variability in stadium IV is considerable, no less than nine different formulae having been observed.

Using the law of anamorphosis, these formulae should give rise to stadium $\mathrm{V}$ specimens with 17,18 , 19, 20, 21 and 22 podous rings. However, no specimens with 17 or 18 podous rings have been observed, and their formulae are therefore shown in parentheses in the diagram. (Notice that the formulae $21+6$ and $22+5$, which are also shown in parentheses for stadium V, are not "necessary" consequences of observed stadium IV formulae, see below).

The observed formulae in stadium $\mathrm{V}$ indicate that stadium VI specimens with 24, 25, 26 and 28 podous rings exist. All these numbers are indeed represented in the material, but there are also stadium VI specimens with 27 podous rings. We therefore need to infer a stadium $\mathrm{V}$ formula which may give rise to 27 podous rings in stadium VI, $21+6$ or $22+5$ being the most probable solutions. Therefore, these formulae appear in parentheses for stadium V.

With stadium VI, we enter a zone where some specimens cannot unequivocally be referred to a specific stadium. The specimen with $28+4$ rings may thus belong to stadium VI (coming from a $22+6$ stadium V specimen), but it may also belong to stadium VII (coming from a $24+4$ stadium VI specimen). Still, the majority of specimens referred 


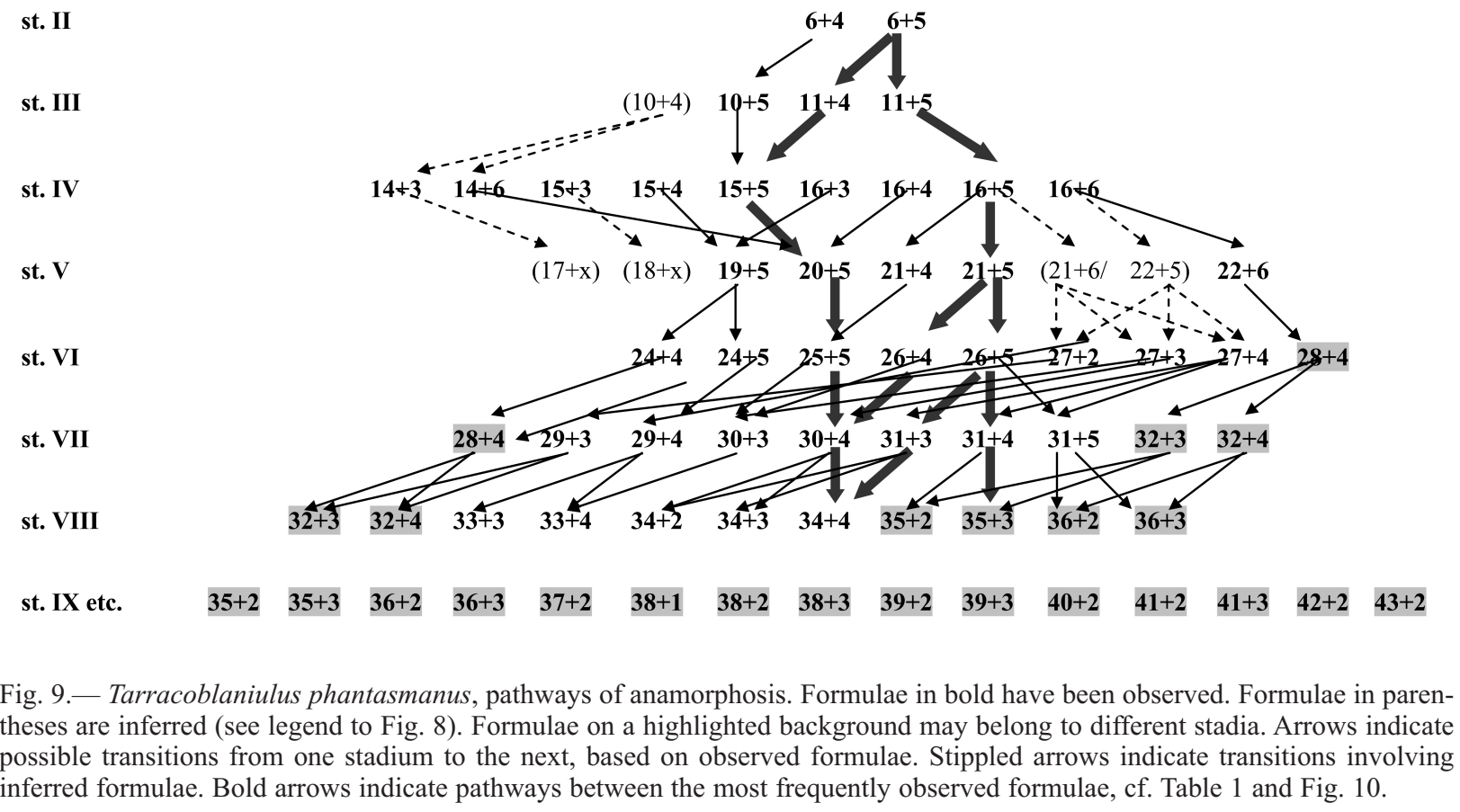

Fig. 9.- Tarracoblaniulus phantasmanus, trayectorias de la anamorfosis. Las fórmulas en negrita son las que han sido observadas en este estudio. Las fórmulas entre paréntesis son las deducidas a partir de las observaciones realizadas (ver leyenda de la Fig. 8). Las fórmulas resaltadas son las que pueden pertenecer a diferentes estadios. Las flechas indican las transiciones posibles entre un estadio y el siguiente. Las flechas en negrita indican la trayectoria entre las fórmulas más frecuentes, cf. Tabla 1 y Fig. 10.

to stadium VI can be assumed actually to belong to this stadium (although unobserved formulae in earlier stadia, which might have lead to additional confusion, cannot be excluded).

The lack of a one-to-one relationship between formula and stadium numbers becomes more predominant in stadia VII and VIII, and from stadium IX onwards, the possibilities are so numerous that it makes no sense trying to refer individual formulae to a particular stadium. For instance, the largest specimen $(43+2)$ could result from a sequence like $19+5($ stadium V) $\rightarrow 24+4 \rightarrow 28+4 \rightarrow 32+3 \rightarrow$ $35+2 \rightarrow 37+2 \rightarrow 39+2 \rightarrow 41+2 \rightarrow 43+2$ and would thus belong to stadium XIII. At the other extreme, it could result from a sequence $21+6$ or $22+5$ (sta$\operatorname{dium} \mathrm{V}) \rightarrow 27+4 \rightarrow 31+4 \rightarrow 35+3 \rightarrow 38+3 \rightarrow 41+2$ $\rightarrow 43+2$, belonging to stadium XI.

The pathways of anamorphosis are illustrated by arrows in Fig. 9. There is a bewildering array of possibilities. However, if the number of observed specimens with each formula is taken into account, it appears that there are a few dominant pathways (Table 1). These are indicated with fat arrows in Fig. 9. Fig. 10 shows a simplified version of the anamor- phosis, up to and including stadium VIII, with only the dominant formulae and pathways included.

The anamorphosis of a handful of blaniulid species has been studied previously, viz. Archiboreoiulus pallidus (Brade-Birks, 1920), Blaniulus guttulatus (Fabricius, 1798), Boreoiulus tenuis (Bigler, 1913), Choneiulus palmatus (Nemec, 1895), Nopoiulus kochii (Gervais, 1847), and Proteroiulus fuscus (Am Stein, 1857) (Brookes, 1974; Brookes \& Willoughby, 1978; Enghoff et al., 1993). Tarracoblaniulus phantasmanus differs from all of these in having four or five apodous rings in stadium II. N. kochii may have three or four apodous rings, all the other species always have a constant number, either four or five. Brachyiulus pusillus (Leach, 1815) of the related family Julidae, like $T$. phantasmanus, may have four or five apodous rings in stadium II, where other studied julids always have five. The observed lack of variability in stadium II in most blaniulids may, however, be due to insufficient sampling, since Brookes \& Willoughby (1978) recorded stadium III specimens of Blaniulus guttulatus with $10-12$ podous rings, suggesting stadium II formulae $6+4,6+5$ and $6+6$. 
Table 1.- Tarracoblaniulus phantasmanus. The most frequent moults (symbolized by $\rightarrow$ ). The table only includes moults where 1) the starting formula is the most frequent one, or is among the most frequent ones, in the stadium in question, and 2) the resulting number of podous rings is the most frequent one, or is among the most frequent ones, in the following stadium.

Tabla 1.- Tarracoblaniulus phantasmanus. Mudas más frecuentes (representadas con $\rightarrow$ ). La tabla sólo incluye las mudas donde: 1) la fórmula de inicio es la más frecuente, o está entre las más frecuentes, en el estadio en cuestión y 2) el número resultante de anillos con patas es el más frecuente, o está entre los más frecuentes, en el estadio siguiente.

\begin{tabular}{lcclcc}
\hline stadium & p.r. & a.r. & & stadium & p.r. \\
\hline II & 6 & 5 & $\rightarrow$ & III & 11 \\
III & 11 & 4 & $\rightarrow$ & IV & 15 \\
& 11 & 5 & $\rightarrow$ & & 16 \\
IV & 15 & 5 & $\rightarrow$ & V & 20 \\
& 16 & 5 & $\rightarrow$ & & 21 \\
V & 20 & 5 & $\rightarrow$ & VI & 25 \\
& 21 & 5 & $\rightarrow$ & & 26 \\
VI & 25 & 5 & $\rightarrow$ & VII & 30 \\
& 26 & 4 & $\rightarrow$ & & 30 \\
& 26 & 5 & $\rightarrow$ & & 31 \\
VII & 30 & 4 & $\rightarrow$ & VIII & 34 \\
& 31 & 3 & $\rightarrow$ & & 34 \\
& 31 & 4 & $\rightarrow$ & & 35 \\
VIII & 34 & 4 & $\rightarrow$ & IX & 38 \\
& 35 & 3 & $\rightarrow$ & & 38 \\
\hline
\end{tabular}

Tarracoblaniulus phantasmanus is further remarkable by the high variability of the number of apodous rings in stadium IV which may have three, four, five or six apodous rings. No other blaniulid species is known to have more than three different numbers of apodous rings in this stadium although a few Julidae are (Enghoff et al., 1993). Given this high degree of early variability, it is no wonder that the correlation between ring formula and stadium number becomes blurred in later stadia.

The single individual with $38+1$ rings is remarkable. In blaniulids in general, the number of apodous rings stabilizes at two in late anamorphosis (Sahli, 1972). Blaniulids with only one apodous ring are rare but have been described in species belonging to several genera (Brolemann, 1923, Sahli, 1972, Enghoff, 1983) ${ }^{3}$.

Brolemann and Sahli used "segment formulae" of the form $\mathrm{z} / \mathrm{w}$ where $\mathrm{z}=$ total number of body rings including telson, and $\mathrm{w}=$ number of apodous rings including telson. Formulae by these authors with 2 in the denominator thus indicate specimens with one apodous ring in our sense.

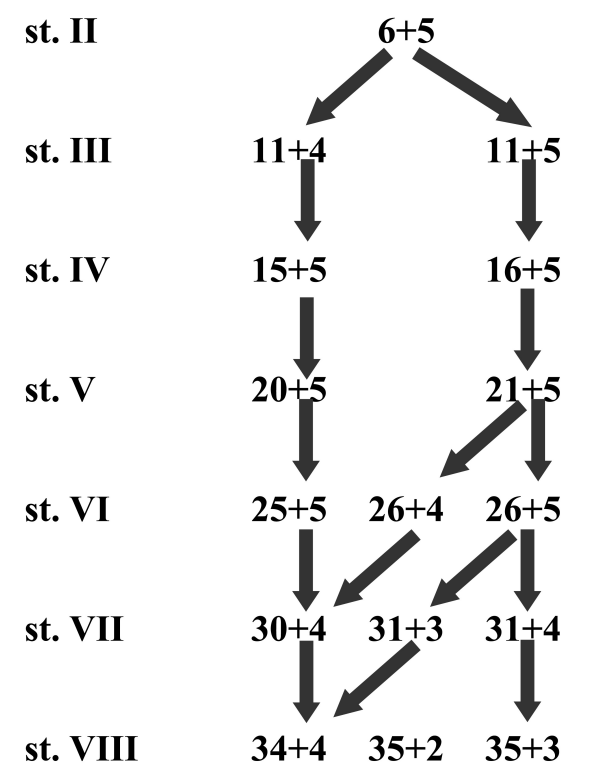

Fig. 10.- Tarracoblaniulus phantasmanus, pathways of anamorphosis, simplified version, up to and including stadium VIII, only dominant formulae and pathways included.

Fig. 10.- Tarracoblaniulus phantasmanus, versión simplificada de las trayectorias de la anamorfosis, hasta el estadio VIII; sólo se han incluido las fórmulas y las trayectorias dominantes.

SEXUAL DIFFERENTIATION AND MATURITY: Without dissection of females, which we have not done except on a few specimens, we cannot say anything about the development of female sexual maturity. For the males, the reduction of leg-pairs 8 and 9 (on body ring 7) signals the onset of sexual differentiation, and the appearance of fully-formed gonopods in body ring seven, together with the characteristically modified mandibles and first legs, signals sexual maturity.

The earliest stadium in which immature males appear is stadium IV where one out of 26 individuals has reduced legs on ring VII (Table 2). In the following stadia, the ratio between specimens with and without reduced legs on ring VII is much more equal, suggesting that not all males are sexually differentiated by stadium IV. (There are, however, remarkably few males in stadia VII and VIII, we have no explanation for this.)

The few (6) mature males in our material either belong to stadium IX or more, or can only ambiguously be assigned to a stadium: two may be either stadium VIII or IX+, and one may be either stadium VII or VIII. In Blaniulus guttulatus, the majority of 


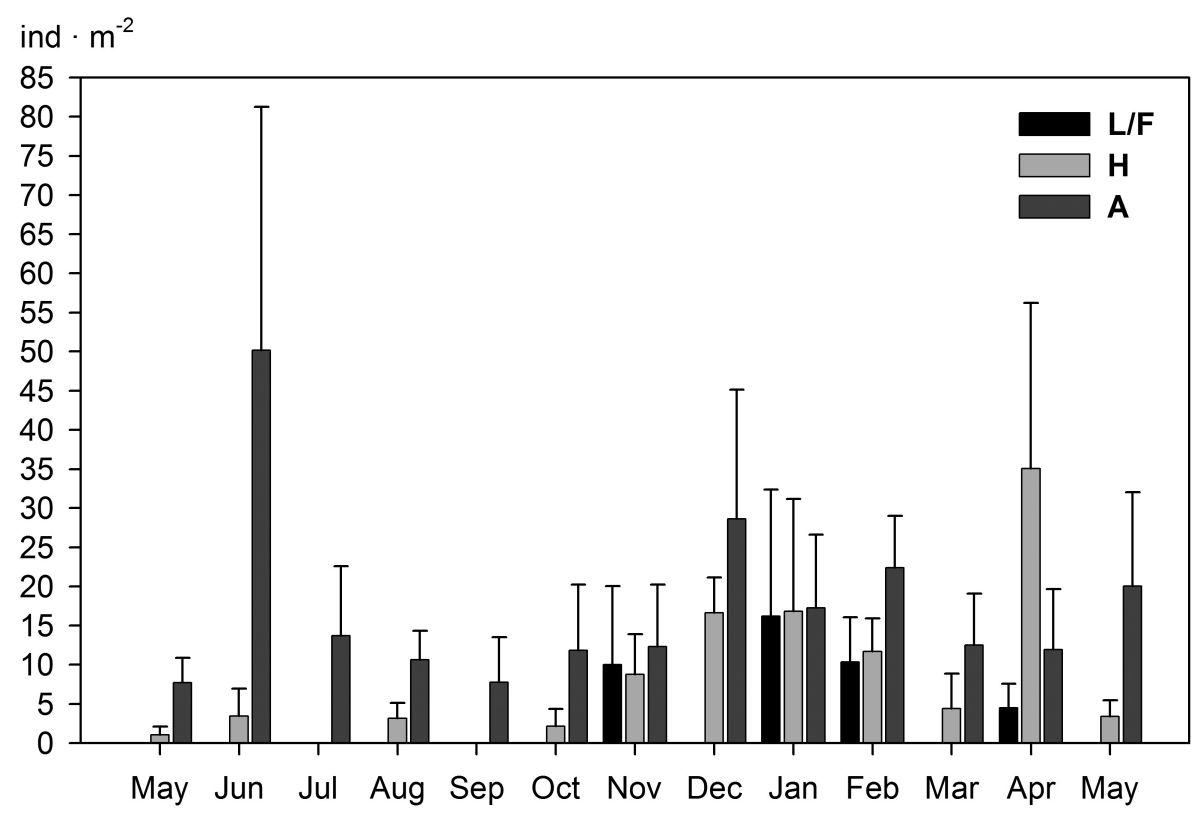

Fig. 11.- Tarracoblaniulus phantasmanus, mean monthly density values (and associated standard errors) in each of the soil horizons (L/F, H, A).

Fig. 11.- Tarracoblaniulus phantasmanus, valores de la densidad media mensual (y sus errores estándar asociados) para cada horizonte del suelo (L/F, H, A).

males mature in stadium IX although a few do so in stadium VIII (Brookes \& Willoughby, 1978). Proteroiulus fuscus is mainly parthenogenetic; however, Rantala $(1970,1974)$ studied a huge amount of material, including reared specimens, and found sev-

Table 2.- Tarracoblaniulus phantasmanus, development of sexual maturity. Numbers of immature and mature males, and females, in stadia IV onward.

Tabla 2.- Tarracoblaniulus phantasmanus, desarrollo de la madurez sexual. Número de machos inmaduros y maduros y de hembras a partir del estadio IV.

\begin{tabular}{lccc}
\hline Stadium & immature males & mature males & females \\
\hline IV & 1 & & 25 \\
V & 4 & & 6 \\
VI & 10 & & 7 \\
VII & 4 & 3 & 17 \\
VIII & 1 & 3 & 8 \\
IX+ & 5 & 3 & \\
$?$ & & & \\
\hline
\end{tabular}

eral males belonging to stadia VIII-XIII. The oldest juvenile males found by Rantala belonged to stadium IX, and mature males in stadia XI and beyond had undergone periodomorphosis (see below).

In addition to mature males, there are also five immature males assigned to stadium IX+, suggesting that some males do not mature until stadium $\mathrm{X}$ or later. Alternatively, the immature males may result from periodomorphosis, a peculiar phenomenon known from several blaniulid and julid millipedes, in which mature males moult into a morphologically immature stadium ("intercalary" male or "Schalt" male), from which they may again moult into a sexually mature stadium (Enghoff et al., 1993). In the absence of direct observation, periodomorphosis may be indicated by the existence of immature males with more podous rings than the largest mature ones. Our small material, however, does not suggest periodomorphosis. The three stadium IX+ mature males have $40+2,41+2$ and $42+2$ body rings, whereas the stadium IX + immature males all have 38 podous $+1-2$ apodous rings.

NOTES ON LIFE CYCLE: Life cycle analyses for blaniulids are available for Proteroiulus fuscus and 
Table 3.- Tarracoblaniulus phantasmanus occurrence of developmental stadia throughout the collecting period. Maximum numbers for stadia II-IV are shown in boldface and larger font.

Tabla 3.- Tarracoblaniulus phantasmanus, número de ejemplares de los distintos estadios de desarrollo capturados durante el período de muestreo. Los valores máximos correspondientes a los estadios II-IV se representan en negrita y un tipo de letra de mayor tamaño.

\begin{tabular}{|c|c|c|c|c|c|c|c|c|c|c|}
\hline Month & st. II & st. III & st. IV & st. V & st. VI & st. VII & st. VIII & st. IX+ & total & unscoreable \\
\hline MAY 02 & & & & & 2 & 2 & & 1 & 5 & 0 \\
\hline JUN 02 & 3 & 8 & 2 & 2 & 4 & 2 & 2 & & 23 & 2 \\
\hline JUL 02 & 1 & 2 & 1 & & 1 & 1 & 1 & 1 & 8 & 0 \\
\hline AUG 02 & 2 & & 3 & 1 & & & & 2 & 8 & 0 \\
\hline SEP 02 & & 1 & & & & & 2 & & 3 & 1 \\
\hline OCT 02 & 2 & 2 & 1 & 1 & & 1 & & & 7 & 1 \\
\hline NOV 02 & & 1 & & 1 & 1 & 3 & 1 & 3 & 10 & 3 \\
\hline DEC 02 & 5 & 3 & 2 & & 2 & & 1 & 6 & 19 & 1 \\
\hline JAN 03 & 4 & 2 & 8 & 2 & 3 & 2 & & 3 & 24 & 1 \\
\hline FEB 03 & 2 & 3 & 5 & 1 & 1 & 4 & 1 & 2 & 19 & 2 \\
\hline MAR 03 & 3 & & & 1 & 2 & & 1 & & 7 & 1 \\
\hline APR 03 & 14 & 2 & 2 & & 1 & 2 & & 1 & 22 & 2 \\
\hline MAY 03 & 4 & & 2 & 1 & & 4 & & 1 & 12 & 1 \\
\hline total & 40 & 24 & 26 & 10 & 17 & 21 & 9 & 20 & 167 & 15 \\
\hline
\end{tabular}

Blaniulus guttulatus (Brookes, 1974; Brookes \& Willoughby, 19784). Brookes and Willoughby based their analyses on the temporal occurrence of the postembryonic stadia, and in the case of B. guttulatus they further counted the number of mature eggs in females collected at different times of the year. They concluded that the life cycle of $P$. fuscus lasts for three years, whereas $B$. guttulatus has a four or even five-year life cycle.

The data we have for $T$. phantasmanus, which do not include egg counts, are not sufficient to draw well-founded conclusions concerning the species' life cycle. The following notes can thus only be regarded as tentative. In Table 3, the temporal occurrence of postembryonic stadia is shown.

The most conspicuous temporal pattern is shown by stadium II, the first mobile stadium. Although stadium II is present throughout the year, there is a maximum (14 out of 40 individuals) in April. Brookes \& Willoughby (1978), building on the observations by Kinkel (1955), noted that the average duration of the period between egg deposi-

4 The second "blaniulid" studied by Brookes (1974), viz. Nemasoma (= Isobates) varicorne C.L. Koch, 1847, is now referred to a separate family, Nemasomatidae (Enghoff, 1981) tion and the appearance of stadium II individuals of $B$. guttulatus is approximately 43 days. If $T$. phantasmanus is similar to B. guttulatus in this respect, the main egg-laying period would be in February.

Stadium III of T. phantasmanus shows a weak peak ( 8 out of 24 individuals) in June, and stadium IV shows a weak peak ( 8 out of 26 individuals) in January. We may thus suggest that eggs laid in February are hatched and have passed the pupoid and first stadia by April where they appear as stadium II. By June, these individuals have moulted into stadium III, and it is not until January of the following year that they have moulted into stadium IV. This suggests summer quiescence, and indeed the number of specimens collected during JulySeptember is very low.

There is no pattern at all in the temporal occurrence of stadia V to VIII. However, stadia IX+ are most frequently collected during winter (14 out of 20 collected in November-February, of which 6 in December alone). This is consistent with a major egg-laying period in February as suggested above. However, we cannot see how many years pass between the second winter, where individuals moult from stadium III to IV, and the winter in which they lay eggs. Given the slow progress from stadium II to 


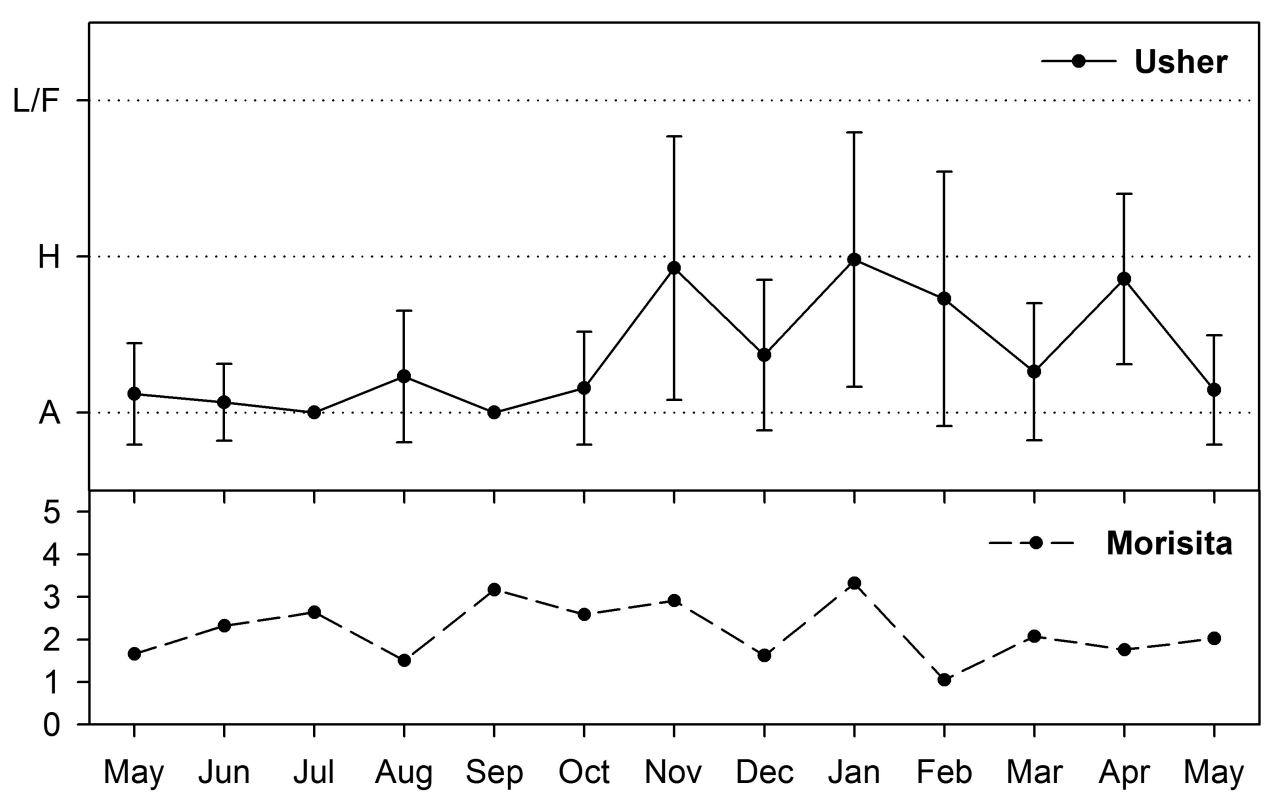

Fig. 12. - Tarracoblaniulus phantasmanus, spatial distribution. Above: vertical distribution, calculated from the Usher index (and associated errors). Below: horizontal distribution in the whole of the soil profile according to Morisita index values.

Fig. 12.- Tarracoblaniulus phantasmanus, distribución espacial. Arriba: distribución vertical, calculada a partir del índice de Usher (y errores estándar asociados). Abajo: distribución horizontal en el total del perfil del suelo, según los valores del índice de Morisita.

IV tentatively suggested by the numbers, at least two additional winters seem probable. The life cycle from egg to egg would thus be of at least three years' duration, as in Proteroiulus fuscus.

TEMPORAL AND SPATIAL DISTRIBUTION: The monthly mean density of the total population was $28.82 \mathrm{ind} / \mathrm{m}^{2}$ across the whole soil profile, divided into $3.16 \pm 1.52$ in horizon $\mathrm{L} / \mathrm{F}, 8.21 \pm 2.76 \mathrm{in} \mathrm{H}$, and $17.46 \pm 3.19$ in $\mathrm{A}$.

Fig. 11 depicts mean monthly density values (and associated standard errors) for the whole of the T. phantasmanus population in each of the soil horizons (L/F, H, A). For horizon A and the whole of the soil profile no significant differences were found in density values between months. On the contrary, analyses showed statistically significant differences in density values between months in horizons $\mathrm{L} / \mathrm{F}(\mathrm{n}=13, \mathrm{KW} \mathrm{p}=0.037)$ and $\mathrm{H}(\mathrm{KW} \mathrm{p}=$ 0.013). However, these differences were not marked enough, and the SNK test could not distinguish between which months they occurred.

Spearman's rank correlation analyses between monthly mean density values in different horizons and abiotic parameters showed that negative correlations occurred between temperature and mean density values of the T. phantasmanus population in all horizons. In horizons $\mathrm{L} / \mathrm{F}\left(\mathrm{C}_{\mathrm{s}}=-0.56\right.$,

Fig.13. - Taraccoblaniulus phantasmanus, detailed vertical distribution per month. The horizontal colums indicate the numbers of specimens in the three sampled strata: litter (L/F), H (humus), and A (upper $3 \mathrm{~cm}$ of the mineral horizon). Specimens are grouped in three classes according to developmental stadia: stadia 2-3 (blue), 4-6 (red), and 7 onward (green). Specimens unassignable to a stadium are shown in purple.

Fig.13. - Tarracoblaniulus phantasmanus, distribución vertical detallada por meses. Las columnas horizontales indican el número de ejemplares en cada uno de los tres horizontes muestreados: hojarasca $(\mathrm{L} / \mathrm{F})$, humus $(\mathrm{H})$ y $\mathrm{A}$ (los primeros $3 \mathrm{~cm}$ del horizonte mineral). Los especímenes se han agrupado en tres clases de acuerdo con el estadio de desarrollo: estadios 2-3 (azul), estadios 4-6 (rojo) y del estadio 7 en adelante (verde). Los especímenes que no se han podido asignar a ningún estadio se han representado en color morado. 

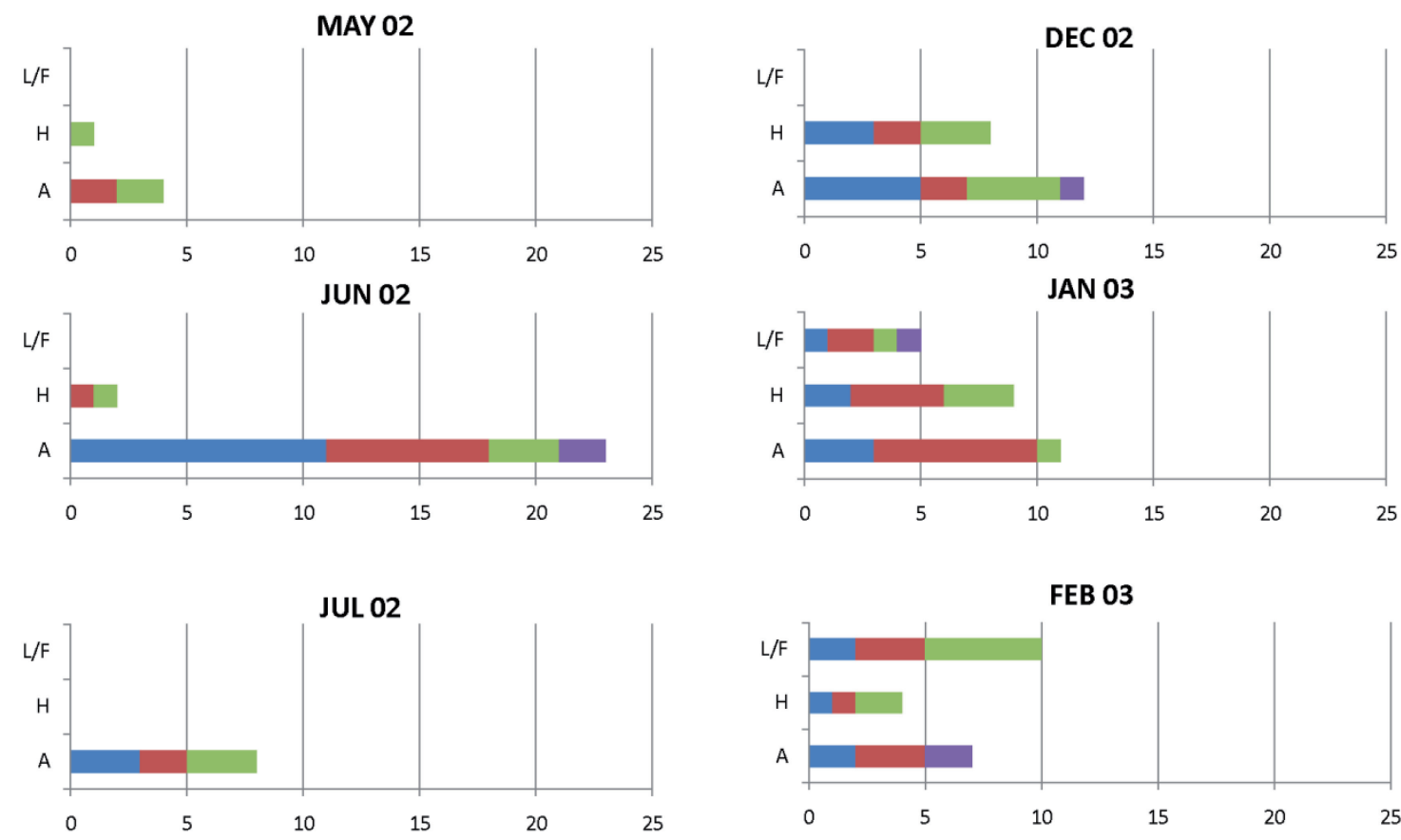

FEB 03
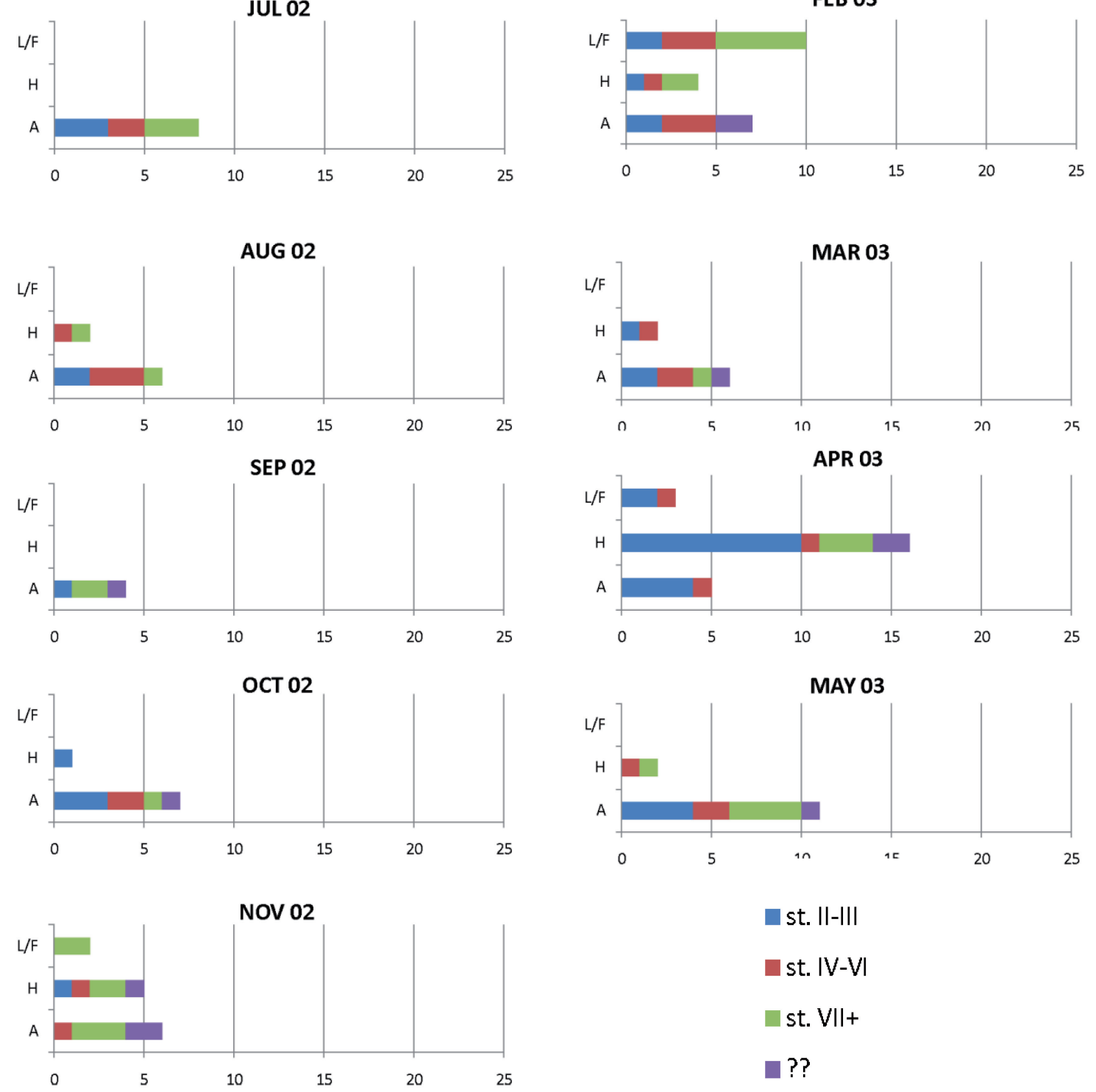

at. ||-|||

st. |V-V|

st. VII+

?? 
$\mathrm{p}<0,005)$ and $\mathrm{H}\left(\mathrm{C}_{\mathrm{s}}=-0.74, \mathrm{p}<0,0005\right)$ these correlations were statistically significant. Regarding rainfall, correlations were positive in horizon A and across the whole profile and negative in horizons $\mathrm{L} / \mathrm{F}$ and $\mathrm{H}$, but they were not statistically significant in any case. These results, together with monthly mean density values obtained, show that T. phantasmanus presents a maximum density in the coldest months and a minimum one in the summer.

Concerning vertical distribution, significant differences between monthly mean densities $(n=13$, KW $p=0.000$, SNK $p<0.05$ ) were found between the different soil levels. Mean values in level A $\left(17.46 \mathrm{ind} / \mathrm{m}^{2}\right)$ were significantly higher than those in $\mathrm{H}\left(8.21 \mathrm{ind} / \mathrm{m}^{2}\right)$ and $\mathrm{L} / \mathrm{F}\left(3.16 \mathrm{ind} / \mathrm{m}^{2}\right)$. Mean values in $\mathrm{H}$ were significantly higher than those in L/F.

The Usher index mean value is $1.37 \pm 0.43(\mathrm{n}=$ 13). Fig. 12 shows that during the spring and summer T. phantasmanus is concentrated in the deepest soil level, mineral horizon A. From autumn, during winter and up to early spring, the population shows a clear tendency to move up towards horizon $\mathrm{H}$ and shyly to horizon L/F. Spearman's rank correlation analyses between monthly Usher index and temperature showed that negative and significant correlations occurred between these values $\left(\mathrm{C}_{\mathrm{s}}=-0.64\right.$, $\mathrm{p}<0,005)$. These correlations agree with results obtained regarding population density distributions across the vertical soil profile. Spearman index values indicate that there was no statistically significant correlation between rainfall and population distribution across the soil profile.

Fig. 13 shows the amount of specimens belonging to each developmental stadium in each horizon for each sampled month. Again, the general trend is that the litter layer is only inhabited by $T$. phantasmanus during winter and early spring (November-April) and the upper mineral layer holds the majority of specimens throughout the year, except for April, where the largest number was found in the humus layer. No difference between developmental stadia could be seen in the vertical distribution.

Concerning horizontal distribution, Morisita index monthly values for each of the horizons were always above 1 (Fig. 12), which indicates that the species is distributed in patches. Mean values of this index obtained in organic horizons $\mathrm{L} / \mathrm{F}$ and $\mathrm{H}$ (3.74 \pm 0.74 and $3.28 \pm 0.46$ respectively) were higher than those calculated for mineral horizon $\mathrm{A}$ $(2.29 \pm 0.16)$ and for the whole of the soil profile $(2.20 \pm 0.19)$. This kind of horizontal distribution is found in most edaphic arthropods, since it seems to favour their search for nourishment and protection or their reproductive activity (Banerjee, 1967; Blower, 1969; Serra et al., 2006).

\section{ACKNOWLEDGEMENTS}

Jan Pedersen and Verner Michelsen, both ZMUC, helped with SEM and extended focus photography, respectively. The students at the course of millipede taxonomy, Chulalongkorn University, Bangkok, helped with unravelling the pathways of anamorphosis.

\section{References}

BANERJEe, B., 1967. Seasonal changes in the distribution of the millipede Cylindroiulus punctatus (Leach) in decaying logs and soil. Journal of Animal Ecology, 36: 171-177.

Blower, J. G., 1969. Age structure of millipede populations in relation to activity and dispersion. In: J. G. Sheals (ed.), The Soil Ecosystem. Systematics Association Publication, London: 209-216.

Brolemann, H.-W., 1923. Biospeologica XLVIII. Blaniulidae. Myriapodes (Première Série). Archives de Zoologie expérimentale et générale, 61: 99-453, pl. i-Xvi.

Brookes, C. H., 1974. The life cycle of Proteroiulus fuscus (Am Stein) and Isobates varicornis (Koch) with notes on the anamorphosis of Blaniulidae. Symposia of the zoological Society of London, 32: 485-501.

Brookes, C. H. \& WilloughBy, J., 1978. An investigation of the ecology and life history of the millipede Blaniulus guttulatus (Bosc) in a British woodland. Abhandlungen und Verhandlungen des naturwissenschaftlichen Vereins Hamburg (NF,) 21/22: 105-114.

Elliot, J. M., 1977. Some methods for the statistical analysis of samples of benthic invertebrates. 2nd edition. Freshwater Biological Association, Scientific Publication No. 25. Windermere. 159 pp.

ENGHOFF, H., 1981. A cladistic analysis and classification of the millipede order Julida. Zeitschrift für zoologische Systematik und Evolutionsforschung, 19: 285-319.

ENGHOFF, H., 1983. Acipes - a Macaronesian genus of millipedes (Diplopoda, Julida, Blaniulidae). Steenstrupia, 9: 137-179.

ENGHOFF, H., 1984. A revision of the Nopoiulinae, with notes on the classification of blaniulid millipedes (Diplopoda: Julida: Blaniulidae). Senckenbergiana biologica, 64: 393-427.

Enghoff, H., Dohle, W. \& Blower, J. G., 1993. Anamorphosis in millipedes (Diplopoda) - the present state of knowledge with some developmental and phylogenetic considerations. Zoological Journal of the Linnean Society, 109: 103-234. 
ENGHOFF, H. \& Shelley, R. M., 1979. A revision of the millipede genus Nopoiulus (Diplopoda, Julida: Blaniulidae). Entomologica Scandinavica, 10: 65-72.

Keuls, M., 1952. The use of the "studentized range" in connection with an analysis of variance. Euphytica, 1: 112-122.

KINKEL, H., 1955. Zur Biologie und Ökologie des getüpfelten Tausendfusses Blaniulus guttulatus Gerv. Zeitschrift für angewandte Entomologie, 37: 401436.

MAURIÈs, J.-P., 1970. Un nouveau Blaniulide cavernicole du Pays Basque français. (Éléments d'une nouvelle classification des Diplopodes Iulides Myriapoda). Annales de Spéléologie, 25: 711-719.

Mauriès, J.-P. \& Vicente, M. C., 1977. Diplópodos cavernícolas nuevos y poco conocidos de España, recoletados por A. Lagar. Descripción de tres géneros nuevos. Miscellanea Zoologica, 4(1): 109-134.

NEWMAN, D., 1939. The distribution of range in samples from a normal population, expressed in terms of an independent estimate of standard deviation. Biometrika, 31: 20-30.

Rantala, M., 1970. Anamorphosis and periodomorphosis of Proteroiulus fuscus (Am Stein) (Diplopoda, Blaniulidae). Bulletin du Muséum national d'Histoire naturelle Paris, (2), 41(Supplement 2): 122-128.

Rantala, M., 1974. Sex ratio and periodomorphosis of Proteroiulus fuscus (Am Stein) (Diplopoda, Blaniulidae). Symposia of the zoological Society of London, 32: 463-469.
SAHLI, F., 1972. Sur le développement post-embryonnaire des Blaniulidae. Annales des Spéléologie, 27: 229-252.

Serra, A., Mateos, E. \& Miquel, C., 2006. A soil population of Glomeris marginata (Villers, 1789) in a Mediterranean forest (Diplopoda: Glomerida). Norwegian Journal of Entomology, 53: 361-374.

SoKAL, R. \& Rohlf, J., 1995. Biometry: the principles and practice of statistics in biological research. 3rd edition. W. H. Freeman and Co. New York. 887 pp.

Spearman, C., 1904. The proof and measurement of association between two things. American Journal of Psychology, 15: 72-101.

UsHer, M. B., 1975. Seasonal and vertical distribution of a population of soil arthropods: Cryptostigmata. Pedobiologia, 15: 364-374.
Recibido, 4-IX-2008

Aceptado, 19-I-2009 Publicado, 29-VI-2009 